\title{
Strategies for the regulation of intracellular calcium in ischemic heart disease
}
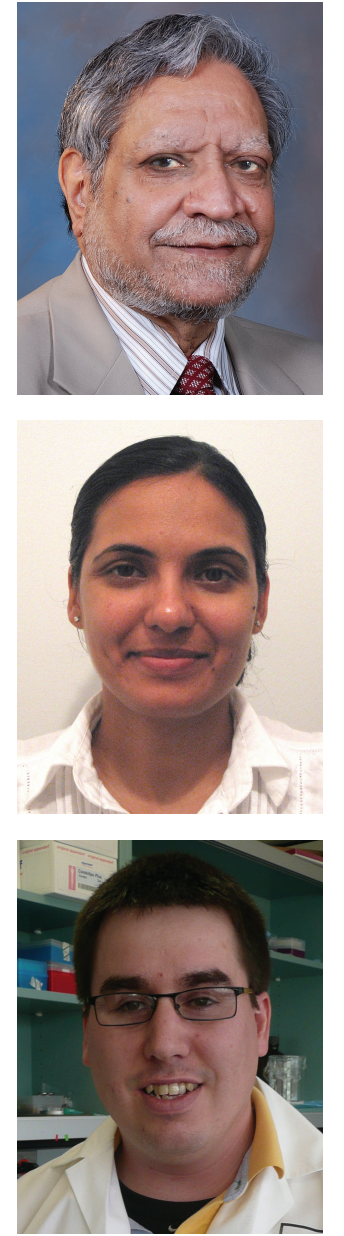

Naranjan S Dhalla ${ }^{\dagger}$, Harjot K Saini-Chohan \& Todd A Dubamel

${ }^{\dagger}$ Author for correspondence Institute of Cardiovascular Sciences, St Boniface General Hospital Research Centre, 351 Tache Avenue, Winnipeg, Manitoba R2H 2A6, Canada Tel.: + 12042353417 Fax: +1 204233 6723; nsdhalla@sbrc.ca

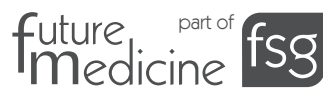

\author{
'Different noncardiomyoctye \\ targets are also activated during \\ the development of ischemic \\ heart disease and are shown to \\ promote the entry of $\mathrm{Ca}^{2+}$ \\ into the myocardium.'
}

In view of the fact that ischemic heart disease is a complex problem having different etiologies such as atherosclerosis, thrombosis and coronary spasm [1-10], it is important to define its nature for understanding the pathogenesis and outlining therapeutic strategies. Narrowing of the coronary artery by formation of atherosclerotic plaque gradually reduces the coronary blood flow over a prolonged time period and this induces a 'low-flow' myocardial ischemia as a consequence of insufficient availability of both oxygen and substrates. Blockade of the coronary vessels by thrombosis or occlusion of the coronary artery by spasm may rapidly stop the blood flow and result in a 'no-flow' myocardial ischemia. Thus, the pattern for the development of ischemic injury under no-flow conditions can be seen to be different from that in low-flow myocardial ischemia. Although myocardial ischemia is a stimulus for the opening of the collateral vessels for supply of blood to the ischemic region [11], the timing for the opening of an existing collateral system or the formation of new vessels is considered to further complicate the type and magnitude of ischemic injury. Nonetheless, ischemic injury is commonly associated with varying degrees of arrhythmias, electrolyte imbalance, energy depletion, ultrastructural damage, apoptosis, necrosis and cardiac dysfunction [1,5-7]. Although institution of reflow is critical for salvage of the ischemic myocardium by procedures such as angioplasty, thrombolytic therapy and coronary bypass surgery, the ischemic injury is further exaggerated (reperfusion injury) if the blood flow is not restored within a certain time period of ischemic insult $[2,5,6]$. It should also be noted that myocardial ischemia results in cell death and the formation of scar tissue (the myocardial infarct); however, the remaining viable myocardium (depending upon the size of the myocardial infarct), becomes hypertrophic and subsequently exhibits the signs and symptoms of congestive heart failure [12-14]. Thus, a great deal of caution should be exercised while discussing the effects of acute and chronic ischemic heart disease as well as early and late stages of myocardial infarction. This article addresses the pathophysiologic events in the ischemic-reperfused myocardium under both acute and chronic ischemic heart disease conditions.

\section{Mechanisms of ischemic-reperfusion injury}

Although risk factors such as diabetes and hypertension, which predispose the myocardium to ischemic injury, can be seen to modify the timecourse as well as the pattern of ischemic changes, it is the reduction in blood flow and subsequent lack of oxygen and substrate that impair energy (ATP) production by mitochondria and produce reactive oxygen species such as superoxide radicals, hydrogen peroxide and hydroxyl radicals [15]. Several noncardiomyocyte targets (Box 1), including sympathetic and purinergic nerves, endothelium, neutrophils, leukocytes, platelets and the renin-angiotensin system, are also considered to participate in the development of ischemic injury [15].

$\therefore$... a great deal of caution should be exercised while discussing the effects of

acute and chronic ischemic heart

disease as well as early and late stages of myocardial infarction.'

These targets are activated (in response to reduced blood flow to the myocardium and subsequent hemodynamic alterations) and release a wide variety of inflammatory cytokines and other mediators to produce oxidative stress [16-23]. It should be mentioned that formation of Ang II due to the activation of the rennin-angiotensin system may produce oxidative stress through its action on NADP/NADPH oxidase, whereas excessive amounts of catecholamines may produce oxyradicals during the process of 
Box 1. Targets that are associated with the development of intracellular $\mathrm{Ca}^{2+}$ overload in the ischemic myocardium.

- Mitochondria in cardiomyocytes: superoxide radicals, hydrogen peroxide and hydroxyradicals

- Sympathetic nerves: catecholamines and oxidation products

- Endothelium: nitric oxide, peroxynitrite and endothelin

- Neutrophils and leukocytes: hypochlorous acid and cytokines

- Platelets: serotonin

- Purinergic nerves: adenosine triphosphate

- Renin-angiotensin system: Ang II

oxidation [24-26]. Furthermore, nitric oxide produced by the endothelium upon combination with superoxide radicals will generate peroxynitrite, a highly reactive oxidant [26].

¿...intracellular $\mathrm{Ca}^{2+}$ overload has been shown to produce activation of proteases and phospholipases, impair energy production, alter gene expression and induce myocardial cell damage and dysfunction.'

Accordingly, it is our contention that oxidative stress caused by the excessive formation of reactive oxygen species, peroxynitrite and hypochlorous acid as well as various hormones, oxidation products of catecholamines and different cytokines sets the stage for ischemic-reperfusion injury to the myocardium. Although oxidative stress can be seen to produce cardiac dysfunction and myocardial cell damage by affecting different subcellular organelles directly, most of its effects (which simulate the ischemic-reperfusion injury) are considered to be mediated through the occurrence of an excessive amount of $\mathrm{Ca}^{2+}$ (intracellular $\mathrm{Ca}^{2+}$ overload) in the myocardium [27-28]. In fact, intracellular $\mathrm{Ca}^{2+}$ overload has been shown to produce activation of proteases and phospholipases, impair energy production, alter gene expression and induce myocardial cell damage and dysfunction $[24,28,29]$.

\section{Calcium handling by subcellular organelles in cardiomyoctyes}

Since intracellular $\mathrm{Ca}^{2+}$ overload is known to play a critical role in the development of cardiac dysfunction and myocardial cell damage in ischemic heart disease [28], it is prudent to discuss various mechanisms that are considered to maintain the intracellular $\mathrm{Ca}^{2+}$ at a low level $\left(10^{-7}\right.$ to $10^{-6} \mathrm{M}$ ) in cardiomyocytes under control conditions. As shown in Table 1, different subcellular organelles, such as the cell membrane (sarcolemma), sarcoplasmic reticulum, mitochondria, nucleus and extracellular matrix, participate in the regulation of intracellular $\mathrm{Ca}^{2+}$ $[7,27,30]$. While sarcolemmal voltage-dependent $\mathrm{Ca}^{2+}$ channels and $\mathrm{Ca}^{2+}$-pump ATPase are directly involved in $\mathrm{Ca}^{2+}$ influx and $\mathrm{Ca}^{2+}$ efflux, respectively, sarcolemmal $\mathrm{Na}^{+}-\mathrm{K}^{+}$ATPase, $\mathrm{Na}^{+}-\mathrm{Ca}^{2+}$ exchanger, $\mathrm{Na}^{+}-\mathrm{H}^{+}$-exchanger and $\mathrm{Na}^{+}$channels are involved in maintaining the intracellular concentration of $\mathrm{Na}^{+}$[31-33]. The sarcolemmal $\mathrm{Na}^{+}-\mathrm{Ca}^{2+}$ exchanger is also considered to be involved in $\mathrm{Ca}^{2+}$ efflux [30,31] whereas sarcolemmal $\mathrm{Ca}^{2+}$ and $\mathrm{Mg}^{2+}$ ecto-ATPase and superficial $\mathrm{Ca}^{2+}$ stores present in the extracellular matrix or glycocalyx have been proposed to participate in $\mathrm{Ca}^{2+}$ entry [30,34-36]. Both $\beta$-adrenoceptors and adenylyl cyclase located in the sarcolemma are also known to promote the entry as well as efflux of $\mathrm{Ca}^{2+}$ upon phosphorylating $\mathrm{Ca}^{2+}$ channels and $\mathrm{Ca}^{2+}$ pump ATPase in cardiomyocytes [31], whereas $\alpha$-adrenoceptors are considered to enhance the entry of $\mathrm{Ca}^{2+}$ through the activation of phospholipase $\mathrm{C}$ [37]. Thus, the sarcolemmal membrane, owing to the presence of multiple $\mathrm{Ca}^{2+}$ handling and regulatory sites, and glycocalyx, owing to the presence of superficial $\mathrm{Ca}^{2+}$ storage mechanism, can be seen to maintain the concentration of intracellular $\mathrm{Ca}^{2+}$ at a low level in comparison with the extracellular concentration of free $\mathrm{Ca}^{2+}(1.25 \mathrm{mM})$.

There is ample evidence to suggest that the sarcoplasmic reticulum is a major intracellular organelle, which, by virtue of the presence of $\mathrm{Ca}^{2+}$-release channels and $\mathrm{Ca}^{2+}$-pump ATPase, is intimately involved in raising and lowering the cytoplasmic concentration of free $\mathrm{Ca}^{2+}$ for cardiac contraction and relaxation, respectively [30].

\section{¿...intracellular organelles ... regulate the cytoplasmic concentration of free $\mathrm{Ca}^{2+}$ when cardiomyoctyes are faced with intracellular $\mathrm{Ca}^{2+}$ overload.}

Furthermore, different mechanisms involving phospholamban, $\mathrm{Ca}^{2+}$-calmodulin protein kinase and inositol-3-phosphate receptors are considered to regulate the $\mathrm{Ca}^{2+}$ release and uptake processes in the sarcoplasmic reticulum [30,38,39]. On the other hand, the mitochondria is considered to be a $\mathrm{Ca}^{2+}$ sink where an antiporter $\mathrm{Ca}^{2+}$-transport system and $\mathrm{Na}^{+}-\mathrm{Ca}^{2+}$ exchange system are located for dealing with high concentrations of $\mathrm{Ca}^{2+}$ and $\mathrm{Na}^{+}$in the cytoplasm $[15,30,40]$. Although the nucleus has also been shown to accumulate a large amount of $\mathrm{Ca}^{2+}$ in 
Table 1. Subcellular structures involved in the regulation of intracellular calcium in cardiomyocytes.

\begin{tabular}{|c|c|}
\hline Structures & Sites \\
\hline Sarcolemma & $\begin{array}{l}\mathrm{Ca}^{2+} \text { channels, } \mathrm{Ca}^{2+} \text {-pump ATPase, } \mathrm{Na}^{+-}-\mathrm{K}^{+} \text {ATPase, } \\
\mathrm{Na}^{+}-\mathrm{Ca}^{2+} \text { exchanger, } \mathrm{Na}^{+}-\mathrm{H}^{+} \text {-exchanger, } \mathrm{Na}^{+} \text {-channels, } \beta \text {-adrenoceptors, } \\
\alpha \text {-adrenoceptors, adenylyl cyclase and } \mathrm{Ca}^{2+}-\mathrm{Mg}^{2+} \text { ecto ATPase }\end{array}$ \\
\hline Sarcoplasmic reticulum & $\begin{array}{l}\mathrm{Ca}^{2+} \text {-release channels, } \mathrm{Ca}^{2+} \text {-pump ATPase, phospholamban, } \\
\mathrm{Ca}^{2+} \text {-calmodulin kinase and inositol-3-phosphate receptors }\end{array}$ \\
\hline Mitochondria & $\mathrm{Ca}^{2+}$-uptake system and $\mathrm{Na}^{+-} \mathrm{Ca}^{2+}$ exchanger \\
\hline Nucleus & $C a^{2+}$-transport system \\
\hline Extracellular matrix & Superficial $\mathrm{Ca}^{2+}$ stores \\
\hline
\end{tabular}

cardiomyoctyes [15,30], its $\mathrm{Ca}^{2+}$-transport system is not well characterized. Thus, intracellular organelles such as sarcoplasmic reticulum, mitochondria and nucleus can be seen to regulate the cytoplasmic concentration of free $\mathrm{Ca}^{2+}$ when cardiomyoctyes are faced with intracellular $\mathrm{Ca}^{2+}$ overload, as in the case of ischemic heart disease.

\section{Mechanisms for the development of intracellular calcium overload}

It is now well known that both the myocardial $\mathrm{Ca}^{2+}$ content and cytoplasmic concentration of free $\mathrm{Ca}^{2+}$ are increased in ischemic heart disease $[28,41-48]$. It should be pointed out that unlike the irreversible stage of ischemic injury, myocardial $\mathrm{Ca}^{2+}$ content is not altered at early phases of ischemic injury. Furthermore, the cytoplasmic concentration of free $\mathrm{Ca}^{2+}$ is only elevated in cardiomyocytes from hearts subjected to irreversible ischemic injury, unlike the reversible ischemic injury $[41,42,49,50]$. Since ischemia produces accumulation of hydrogen, the stimulation of the sarcolemmal $\mathrm{Na}^{+}-\mathrm{H}^{+}$exchanger followed by the activation of the sarcolemmal $\mathrm{Na}^{+}-\mathrm{Ca}^{2+}$ exchanger is considered to be a mechanism for the increase of $\mathrm{Ca}^{2+}$ influx as well as cytoplasmic levels of free $\mathrm{Ca}^{2+}$ in ischemic myocardium [7,32,51]. However, this mechanism is confounded by the fact that inhibition of the $\mathrm{Na}^{+}-\mathrm{H}^{+}$exchanger with agents such as methyl$N$-isobutyl amiloride was observed to increase the cytoplasmic concentration of hydrogen, which caused the release of $\mathrm{Ca}^{2+}$ from the sarcoplasmic reticulum and resulted in an increase in the cytoplasmic concentration of $\mathrm{Ca}^{2+}[32,52]$. Thus, inhibitors of the $\mathrm{Na}^{+}-\mathrm{H}^{+}$exchanger may not be a suitable therapy for the treatment of ischemic heart disease. Since sarcolemmal $\mathrm{Na}^{+}-\mathrm{K}^{+}$ATPase is also inhibited in both ischemic and ischemic-reperfused heart [53-55], this can be seen to increase the intracellular concentration of $\mathrm{Na}^{+}$followed by the activation of the sarcolemmal $\mathrm{Na}^{+}-\mathrm{Ca}^{2+}$ exchanger and an increase in the intracellular concentration of free $\mathrm{Ca}^{2+}$. Increased entry of $\mathrm{Na}^{+}$upon the opening of sarcolemmal $\mathrm{Na}^{+}$-channels in the ischemic myocardium can also be seen to promote the activation of the sarcolemmal $\mathrm{Na}^{+}-\mathrm{Ca}^{2+}$ exchanger and promote the entry of $\mathrm{Ca}^{2+}$. Thus, the activation of the sarcolemmal $\mathrm{Na}^{+}-\mathrm{H}^{+}$exchanger and $\mathrm{Na}^{+}$channels as well as the inhibition of the sarcolemmal $\mathrm{Na}^{+}-\mathrm{K}^{+}$ATPase can be seen to increase the intracellular concentration of $\mathrm{Na}^{+}$and thereby increase the entry of $\mathrm{Ca}^{2+}$ through the participation of the sarcolemmal $\mathrm{Na}^{+}-\mathrm{Ca}^{2+}$ exchanger. Accordingly, it appears that inhibitors of the $\mathrm{Na}^{+}-\mathrm{Ca}^{2+}$ exchanger reverse mode would be of great promise for reducing the intracellular $\mathrm{Ca}^{2+}$ overload and subsequent ischemic-reperfusion injury.

Activation of voltage-dependent $\mathrm{Ca}^{2+}$ channels by the accumulation of long-chain acylcarnitine and fatty acids in the sarcolemmal membrane in the ischemic heart is also considered to promote the entry of $\mathrm{Ca}^{2+}[24]$.

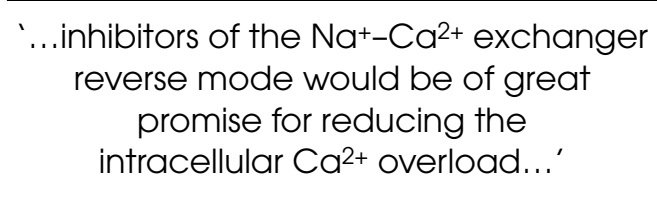

In this regard, different types of $\mathrm{Ca}^{2+}$-antagonists have been shown to produce beneficial effects against ischemic-reperfusion injury by reducing the development of intracellular $\mathrm{Ca}^{2+}$ overload [25,56,57]. Although sarcolemmal $\mathrm{Ca}^{2+}-\mathrm{Mg}^{2+}$ ecto-ATPase and superficial $\mathrm{Ca}^{2+}$-stores in the extracellular matrix have also been suggested to participate in the development of intracellular $\mathrm{Ca}^{2+}$ overload in the ischemic-reperfused myocardium [35], new 
agents need to be developed for the control of $\mathrm{Ca}^{2+}$ through these mechanisms. The participation of both $\beta$-adrenoceptors and $\alpha$-adrenoceptors in the sarcolemmal membrane for promoting $\mathrm{Ca}^{2+}$ influx is evident from the fact that a large amount of catecholamines are released from the sympathetic nerve ending [24] and different $\beta$-adrenoceptor and $\alpha$-adrenoceptor blocking agents are found to exert beneficial effects in ischemic heart disease [26].

'...control of $\mathrm{Ca}^{2+}$ in
ischemic-reperfused myocardium
cannot be achieved by any single drug
affecting one site, but instead a
combination therapy modifying various
sites is required for reducing intracellular
$\mathrm{Ca}^{2+}$ overload in the heart.'

Since release of catecholamines from the sympathetic nerve endings is accompanied by the release of ATP, and since the extracellular ATP has been shown to increase $\mathrm{Ca}^{2+}$ influx in cardiomyocytes [42,58], it is possible that ATP-induced signal transduction may be involved in the induction of intracellular $\mathrm{Ca}^{2+}$-overload in ischemic heart disease. Activation of purinergic nerves and the serotonergic system as well as of platelets is also apparent in the development of intracellular $\mathrm{Ca}^{2+}$ overload because an ATP-receptor antagonist (pyridoxal 5'-phosphate) and a serotoninreceptor antagonist (sarpogrelate) were observed to attenuate ischemic-reperfusion injury [58-60]. In addition to the involvement of various sarcolemmal sites for promoting the entry of $\mathrm{Ca}^{2+}$ in the ischemic-reperfused myocardium, changes in both $\mathrm{Ca}^{2+}$-release channels and the $\mathrm{Ca}^{2+}$-uptake system in the sarcoplasmic reticulum have been identified to increase the cytoplasmic concentration of $\mathrm{Ca}^{2+}$ in cardiomyocytes [61-63]. However, no satisfactory intervention except ischemic preconditioning has yet become available for the stabilization of sarcoplasmic reticulum function in ischemic heart disease [62-64]. It should be emphasized that mitochondria are known to serve as a $\mathrm{Ca}^{2+}$ sink during the development of intracellular $\mathrm{Ca}^{2+}$ overload in the ischemic reperfused heart and this mitochondria $\mathrm{Ca}^{2+}$ overload impairs their ability to produce ATP [40,45]. Ischemia-reperfusion has also been shown to produce marked changes in cardiac gene expression for both sarcoplasmic reticulum and sarcolemmal proteins [53,61-63] and this can be seen to affect cardiac function in the late stages of ischemic heart disease.

\section{Subcellular defects \& oxidative stress}

From the foregoing discussion, it is clear that not only is the myocardial $\mathrm{Ca}^{2+}$ content increased but the intracellular concentration of free $\mathrm{Ca}^{2+}$ is also increased during the irreversible damage caused by ischemic heart disease. This would imply that the net gain of intracellular $\mathrm{Ca}^{2+}$ in cardiomyocytes is from extracellular sources and this involves multisite mechanisms in the sarcolemma, whereas the increase in the cytoplasmic concentration of free $\mathrm{Ca}^{2+}$ may be caused by changes in the $\mathrm{Ca}^{2+}$-handling abilities of the subcellular organelles such as the sarcoplasmic reticulum, mitochondria and nucleus. It should be noted that ischemia-reperfusion and hypoxia-reoxygenation have been shown to produce marked changes in the sarcolemmal $\mathrm{Na}^{+}-\mathrm{K}^{+} \quad$ ATPase, $\mathrm{Na}^{+}-\mathrm{Ca}^{2+}$ exchange, $\mathrm{Ca}^{2+}$-pump ATPase and $\mathrm{Ca}^{2+}$ channel [7], the sarcoplasmic reticulum $\mathrm{Ca}^{2+}$-release channel and $\mathrm{Ca}^{2+}$-pump ATPase [7] as well as mitochondrial function $[7,40]$. Such alterations favoring the development of intracellular $\mathrm{Ca}^{2+}$ overload appear to be due to the occurrence of oxidative stress since antioxidant therapy and ischemic preconditioning, which reduces oxidative stress, were found to attenuate these changes in ischemic-reperfused hearts $[18,52,54,60,63]$. Furthermore, these alterations were simulated by interventions that generate oxidative stress. In fact, the increased cytoplasmic concentration of free $\mathrm{Ca}^{2+}$ in cardiomyocytes following ischemia-reperfusion was not only attenuated by antioxidant therapy but was also stimulated by interventions generating oxidative stress $[41,42]$.

\section{'The occurrence of oxidative stress from various sources appears to account for the development of intracellular $\mathrm{Ca}^{2+}$ overload.'}

On the other hand, catecholamine- and ATP-induced increases in the cytoplasmic concentration of free $\mathrm{Ca}^{2+}$ were depressed in the ischemic-reperfused hearts [41,42], which may be caused by alterations in the receptormediated signal transduction mechanisms located in the sarcolemmal membrane [41,42]. Since ischemia-reperfusion has also been reported to produce dramatic changes in both cardiac genes corresponding to different $\mathrm{Ca}^{2+}$-handling proteins in the sarcoplasmic reticulum and sarcolemmal membrane [53,60-62], and these changes were attenuated by antioxidant therapy $[53,60,63]$, it appears that these defects may account for 
remodeling of the membrane system and, thus, may result in $\mathrm{Ca}^{2+}$-handling defects in the cardiomyocytes under chronic ischemic heart disease conditions. In view of the multisite defects in ischemic heart disease for inducing intracellular $\mathrm{Ca}^{2+}$ overload in cardiomyocytes, it is emphasized that the control of $\mathrm{Ca}^{2+}$ in ischemic-reperfused myocardium cannot be achieved by any single drug affecting one site, but instead a combination therapy modifying various sites is required for reducing intracellular $\mathrm{Ca}^{2+}$ overload in the heart.

\section{Conclusion}

While both acute and chronic phases of ischemic heart disease are associated with cardiac dysfunction, arrhythmias, myocardial cell damage, apoptosis and necrosis, the ischemia-reperfusion injury has been observed to produce a net gain in myocardial $\mathrm{Ca}^{2+}$ content and an increase in the cytoplasmic concentration of free $\mathrm{Ca}^{2+}$. Several cardiomyocyte-associated mechanisms, including defects in $\mathrm{Ca}^{2+}$ handling and regulatory proteins in both the sarcolemma and sarcoplasmic reticulum, have been identified for the development of intracellular $\mathrm{Ca}^{2+}$ overload following ischemic-reperfusion injury. Different noncardiomyoctye targets are also activated during the development of ischemic heart disease and are shown to promote the entry of $\mathrm{Ca}^{2+}$ into the myocardium. The occurrence of oxidative stress from various sources appears to account for the development of intracellular $\mathrm{Ca}^{2+}$ overload. Thus, a multidrug therapy should be considered for the reduction of intracellular $\mathrm{Ca}^{2+}$ overload and subsequent attenuation of pathophysiological alterations associated with ischemic heart disease.

\section{Financial \& competing interests disclosure}

This study was supported by a grant from the Canadian Institutes of Health Research. Harjot K Saini-Chohan was a predoctoral fellow of the Heart \& Stroke Foundation of Canada. Todd A Duhamel, a postdoctoral fellow, was supported by the CIHR/Heart and Stroke Foundation of Canada IMPACT Program. The authors have no other relevant affiliations or financial involvement with any organization or entity with a financial interest in or financial conflict with the subject matter or materials discussed in the manuscript apart from those disclosed.

No writing assistance was utilized in the production of this manuscript.

\section{Bibliography}

1. Jennings RB, Reimer KA: The cell biology of acute myocardia ischemia. Annu. Rev. Med. 42, 225-246 (1991).

2. Hearse DJ, Bolli R: Reperfusion induced injury: manifestations, mechanisms, and clinical relevance. Cardiovasc. Res. 26, 101-108 (1992).

3. Bolli R, Marban E: Molecular and cellular mechanisms of myocardial stunning. Physiol. Rev. 79, 609-634 (1999).

4. Dhalla NS, Elmoselhi AB, Hata T, Makino N: Status of myocardial antioxidants in ischemia-reperfusion injury. Cardiovasc. Res. 47, 446-456 (2000).

5. Dhalla NS, Golfman L, Takeda S, Takeda N, Nagano M: Evidence for the role of oxidative stress in acute ischemic heart disease: a brief review. Can. J. Cardiol. 15, 587-593 (1999).

6. Piper HM, Meuter K, Schafer C: Cellular mechanisms of ischemia-reperfusion injury. Ann. Thorac. Surg. 75, S644-S648 (2003).

7. Dhalla NS, Saini HK, Tappia PS, Sethi R, Mengi SA, Gupta SK: Potential role and mechanisms of subcellular remodeling in cardiac dysfunction due to ischemic heart disease. J. Cardiovasc. Med. 8, 238-250 (2007).

8. Karmazyn M, Beamish RE, Fliegel L, Dhalla N: Adrenochrome induced coronary artery constriction in the rat heart. J. Pharmacol. Exp. Ther. 219, 225-230 (1981).
9. Saini HK, Takeda N, Goyal RK, Kumamoto H, Arneja AS, Dhalla NS: Therapeutic potentials of sarpogrelate in cardiovascular disease. Cardiovasc. Drug Rev. 22, 27-54 (2004).

10. Singh RB, Mengi SA, Xu Y-J, Arneja AS, Dhalla NS: Pathogenesis of atherosclerosis: a multifactorial process. Exp. Clin. Cardol. 7, 40-53 (2002).

11. Pandya NM, Dhalla NS, Santani DD: Angiogenesis - a new target for future therapy. Vascul. Pharmacol. 44, 265-274 (2006).

12. Dixon IMC, Lee SL, Dhalla NS: Nitrendipine binding in congestive heart failure due to myocardial infarction. Circ. Res. 66, 782-788 (1990).

13. Dhalla NS, Dixon IMC, Rupp H, Barwinsky J: Experimental congestive heart failure due to myocardial infarction: Sarcolemmal receptors and cation transporters. Basic Res. Cardiol. 86(Suppl. 3), 13-23 (1991).

14. Dhalla NS, Afzal N, Beamish RE, Naimark B, Takeda N, Nagano M: Pathophysiology of cardiac dysfunction in congestive heart failure. Can. J. Cardiol. 9, 873-887 (1993).

15. Dhalla NS, Temsah RM, Netticadan T: Role of oxidative stress in cardiovascular diseases. J. Hypertens. 18, 655-673 (2000).

16. Singal PK, Kapur N, Dhillon KS, Beamish RE, Dhalla NS: Role of free radicals in catecholamine-induced cardiomyopathy.
Can. J. Physiol. Pharmacol. 60, 1390-1397 (1982).

17. Beamish RE, Das PK, Karmazyn M, Dhalla NS: Prostaglandins and heart disease. Can. J. Cardiol. 1, 66-74 (1985).

18. Turan B, Saini HK, Zhang M, Prajapati D, Elimban V and Dhalla NS: Selenium improves cardiac function by attenuating the activation of $\mathrm{NF}_{\kappa} \mathrm{B}$ due to ischemia-reperfusion injury. Antioxid. Redox Signal7, 1388-1397 (2005).

19. Tappia PS, Hata T, Hozaima L, Sandhu MS, Panagia V, Dhalla NS: Role of oxidative stress in catecholamine-induced changes in cardiac sarcolemmal Ca ${ }^{2+}$ transport. Arch. Biochem. Biophys. 387, 85-92 (2001).

20. Takeo S, Nasa Y, Tanonaka K et al.: Role of cardiac rennin-angiotensin system in sarcoplasmic reticulum function and gene expression in ischemic-reperfused hearts. Mol. Cell. Biochem. 212, 227-235 (2000).

21. Zhang M, Xu Y-J, Saini HK, Turan B, Liu PP, Dhalla NS: Pentoxifylline attenuates cardiac dysfunction and reduces TNF- $\alpha$ level in the ischemic-reperfused heart. Am. J. Physiol. Heart Circ. Physiol. 289, H832-H839 (2005).

22. Saini HK, Xu Y-J, Zhang M, Liu PP, Kirshenbaum LA, Dhalla NS: Role of tumor necrosis factor- $\alpha$ and other cytokines in ischemia-reperfusion induced injury in the heart. Exp. Clin. Cardiol. 10, 213-222 (2005). 
23. Chohan PK, Singh RB, Dhalla NS, Netticadan T: L-arginine administration recovers sarcoplasmic reticulum function in ischemic/reperfused hearts by preventing calpain activation. Cardiovasc. Res. 69, 152-163 (2006).

24. Temsah RM, Netticadan T, Dhalla NS: Mechanisms of cellular alterations due to ischemia-reperfusion injury in the heart. In: Myocardial Ischemia and Preconditioning. Dhalla NS, Takeda N, Singh M, Lukas A (Eds). Kluwer Academic Publishers, Boston, MA, USA, 149-164 (2003).

25. Zhang M, Sallam T, Xu Y-J, Dhalla NS: Modification of ischemia-reperfusioninduced injury by cardioprotective interventions. In: Myocardial Protection. Salerno T, Ricci M (Eds). Blackwell Publishing-Futura, NY, USA, 18-32 (2004).

26. Singh RB, Dhalla NS: Mechanisms of cardioprotection against ischemia-reperfusion injury. In: Pathophysiology of Cardiovascular Disease. Dhalla NS, Rupp H, Angel A, Pierce GN (Eds). Kluwer Academic Publishers, Boston, MA, USA, 303-326 (2004)

27. Saini HK, Machackova J, Dhalla NS: Role of reactive oxygen species in ischemic preconditioning of subcellular organelles in the heart. Antioxid. Redox Signal. 6 , 393-404 (2004).

28. Dhalla NS, Temsah RM, Netticadan T, Sandhu MS: Calcium overload in ischemia/reperfusion injury. In: Heart Physiology and Pathophysiology (4th Edition). Sperelakis N, Kurachi Y, Terzic A, Cohen M (Eds). Academic Press, San Diego, CA, USA, 949-965 (2001).

29. Singh RB, Dandekar SP, Elimban V, Gupta SK, Dhalla NS: Role of proteases in the pathophysiology of cardiac diseases. Mol. Cell. Biochem. 263, 241-256 (2004).

30. Dhalla NS, Pierce GN, Panagia V, Singal PK, Beamish RE: Calcium movements in relation to heart function. Basic Res. Cardiol. 77, 117-139 (1982).

31. Saini HK, Tripathi ON, Zhang $S$, Elimban V, Dhalla NS: Involvement of $\mathrm{Na}^{+}-\mathrm{Ca}^{2+}$ exchanger in catecholamineinduced increase in intracellular calcium in cardiomyocytes. Am. J. Physiol. Heart Circ. Physiol. 290, H373-H380 (2006).

32. Saini HK, Dhalla NS: Modification of intracellular calcium concentration in cardiomyoctyes by inhibition of sarcolemmal $\mathrm{Na}^{+}-\mathrm{H}^{+}$exchanger. Am. J. Physiol. Heart Circ. Physiol. 291, H2790-H2800 (2006).
33. Saini HK, Dhalla NS: Sarcolemmal cation channels and exchangers modify the increase in intracellular calcium in cardiomyocytes upon inhibiting $\mathrm{Na}^{+}-\mathrm{K}^{+}$ATPase. Am. J. Physiol. Heart Circ. Physiol. 293, H169-H181 (2007).

34. Dhalla NS, Zhao D: Cell membrane $\mathrm{Ca}^{2+} / \mathrm{Mg}^{2+}$ ATPase. Prog. Biophys. Mol. Biol. 52, 1-37 (1988).

35. Dhalla NS, Zhao D: Possible role of sarcolemmal Ca ${ }^{2+} / \mathrm{Mg}^{2+}$ ATPase in heart function. Magnes. Res. 2, 161-172 (1989).

36. Kaneko M, Singal PK, Dhalla NS: Alterations in heart sarcolemmal $\mathrm{Ca}^{2+}-$ ATPase and $\mathrm{Ca}^{2+}$-binding activities due to oxygen free radicals. Basic Res. Cardiol. 85, 45-54 (1990).

37. Tappia PS, Singal T, Dent MR, Asemu G, Mangat R, Dhalla NS: Phospholipidmediated signaling in diseased myocardium. Future Lipidol. 1, 701-717 (2006).

38. Dhalla NS, Temsah RM: Sarcoplasmic reticulum and cardiac oxidative stress: an emerging target for heart disease. Expert Opin. Ther. Targets 5, 205-217 (2001)

39. Singh RB, Chohan PK, Dhalla NS, Netticadan T: The sarcoplasmic reticulum proteins are targets for calpain action in the ischemic-reperfused heart. J. Mol. Cell. Cardiol. 37, 101-110 (2004)

40. Makazan Z, Saini HK, Dhalla NS: Role of oxidative stress in alterations of mitochondrial function in the ischemic reperfused hearts. Am. J. Physiol. Heart Circ Physiol. 292, H1986-H1994 (2007).

41. Saini HK, Dhalla NS: Defective calcium handling in cardiomyocytes isolated from hearts subjected to ischemia-reperfusion. Am. J. Physiol. Heart Circ. Physiol. 288, H2260-H2270 (2005).

42. Saini HK, Elimban V, Dhalla NS. Attenuation of extracellular ATP response in cardiomyocytes isolated from hearts subjected to ischemia-reperfusion. Am. J. Physiol. Heart Circ. Physiol. 289, H614-H623 (2005).

43. Kihara Y, Grossman W, Morgan JP: Direct measurement of changes in intracellular calcium transients during hypoxia, ischemia, and reperfusion of the intact mammalian heart. Circ. Res. 65, 1029-1044 (1989).

44. Kim SJ, Kudej RK, Yatani A et al.: A novel mechanism for myocardial stunning involving impaired $\mathrm{Ca}^{2+}$ handling. Circ. Res. 89, 831-837 (2001)

45. Miyamae M, Camacho SA, Weiner MW, Figueredo VM: Attenuation of postischemic reperfusion injury is related to prevention of $\mathrm{Ca}^{2+}$ overload in rat hearts. Am. J. Physiol. Heart Circ. Physiol. 271, H2145-H2153 (1996).
46. Piper HM, Garcia-Dorado D: Prime causes of rapid cardiomyocyte death during reperfusion. Ann. Thorac. Surg. 68, 1913-1999 (1999).

47. Steenbergen C, Fralix TA, Murphy E: Role of increased cytosolic free calcium concentration in myocardial ischemic injury. Basic Res. Cardiol. 88, 456-470 (1993).

48. Tani M, Neely JR: Role of intracellular $\mathrm{Na}^{+}$ in $\mathrm{Ca}^{2+}$ overload and depressed recovery of ventricular function of reperfused ischemic rat hearts. Possible involvement of $\mathrm{H}^{+}-\mathrm{Na}^{+}$ and $\mathrm{Na}^{+}-\mathrm{Ca}^{2+}$ exchange. Circ. Res. 65 , 1045-1056 (1989).

49. Chandrashekhar Y, Prahash AJ, Sen S, Gupta S, Anand IS: Cardiomyocytes from hearts with left ventricular dysfunction after ischemia-reperfusion do not manifest contractile abnormalities. J. Am. Coll. Cardiol. 34, 594-602 (1999).

50. Meissner A, Morgan JP: Contractile dysfunction and abnormal $\mathrm{Ca}^{2+}$ modulation during postischemic reperfusion in rat heart. Am. J. Physiol. Heart Circ. Physiol. 268, H100-H111 (1995).

51. Karmazyn M: Amiloride enhances postischemic ventricular recovery: possible role of $\mathrm{Na}^{+}-\mathrm{H}^{+}$exchange. Am. J. Physiol. Heart Circ. Physiol. 255, H608-H615 (1988).

52. Saini HK, Elimban V, Ozcelikay AT, Dhalla NS: Mechanisms of cardiodepression by an $\mathrm{Na}^{+}-\mathrm{H}^{+}$exchange inhibitor methyl$\mathrm{N}$-isobutyl amiloride (MIA) on the heart: lack of beneficial effects in ischemiareperfusion injury. Can. J. Physiol. Pharmacol. 85, 67-78 (2007)

53. Elmoselhi AB, Lukas A, Ostadal P, Dhalla NS: Preconditioning attenuates ischemia-reperfusion-induced remodeling of $\mathrm{Na}^{+}-\mathrm{K}^{+}$-ATPase in hearts. Am. J. Physiol. Heart Circ. Physiol. 285, H1055-H1063 (2003).

54. Ostadal P, Elmoselhi AB, Zdobnicka I, Lukas A, Chapman D, Dhalla NS: Ischemiareperfusion alters gene expression of $\mathrm{Na}^{+}-\mathrm{K}^{+}$ ATPase isoforms in rat heart. Biochem. Biophys. Res. Commun. 306, 457-462 (2003).

55. Ostadal P, Elmoselhi AB, Zdobnicka I, Lukas A, Elimban V, Dhalla NS: Role of oxidative stress in ischemia-reperfusioninduced changes in $\mathrm{Na}^{+}-\mathrm{K}^{+}$-ATPase isoform expression in rat heart. Antioxid. Redox Signal. 6, 914-923 (2004).

56. Gu XH, Dillon JS, Nayler WG: Dihydropyridine binding sites in aerobically perfused, ischemic, and reperfused rat hearts: effect of temperature and time. J. Cardiovasc. Pharmacol. 12, 272-278 (1988). 
57. Liu X, Engelman RM, Wei Z et al.: Attenuation of myocardial reperfusion injury by reducing intracellular calcium overloading with dihydropyridines. Biochem. Pharmacol. 45, 1333-1341 (1993).

58. Wang X, Dakshinamurti K, Musat S, Dhalla NS: Pyridoxal 5'-phosphate is an ATP-receptor antagonist in freshly isolated rat cardiomyocytes. J. Mol. Cell. Cardiol. 31, 1063-1072 (1999).

59. Temsah RM, Kumamoto H, Takeda N, Dhalla NS: Sarpogrelate diminishes changes in energy stores and ultrastructure of the ischemic-reperfused rat heart. Can. J. Physiol. Pharmacol. 79, 761-767 (2001).

60. Kandzari DE, Dery J-P, Armstrong PW et al: : MC-1 (pyridoxal 5'-phosphate): novel therapeutic applications to reduce ischaemic injury. 14, 1435-1442 (2005).
61. Temsah RM, Netticadan T, Chapman D, Takeda S, Mochizuki S, Dhalla NS: Alterations in sarcoplasmic reticulum function and gene expression in ischemia-reperfused rat heart. Am. J. Physiol. Heart Circ. Physiol. 277, H584-H594 (1999).

62. Temsah RM, Dyck C, Netticadan T, Chapman D, Elimban V, Dhalla NS: Effect of $\beta$-adrenoceptor blockers on sarcoplasmic reticular function and gene expression in the ischemic-reperfused heart. J. Pharmacol. Exp. Ther. 293, 15-23 (2000).

63. Dhalla NS, Duhamel TA: The paradoxes of reperfusion in the ischemic heart. Heart Metab. 37, 31-34 (2007).

64. Temsah RM, Kawabata K, Chapman D, Dhalla NS: Preconditioning prevents alterations in cardiac SR gene expression due to ischemia-reperfusion. Am. J. Physiol. Heart Circ. Physiol. 282, 1461-1466 (2002).

\section{Affiliations}

- Naranjan S Dhalla

Institute of Cardiovascular Sciences, St Boniface General Hospital Research Centre, 351 Tache Avenue, Winnipeg, Manitoba, R2H 2 A6 Canada Tel.: +1 2042353417 ;

Fax: +1 2042336723

nsdhalla@sbrc.ca

- Harjot KSaini-Chohan Institute of Cardiovascular Sciences, St Boniface General Hospital Research Centre, and,

Department of Physiology, Faculty of Medicine, University of Manitoba, Winnipeg, Canada Tel.: + 12042353417 ;

Fax: +1 204233 6723;

harjot.chohan@gmail.com

- Todd A Duhamel Institute of Cardiovascular Sciences, St Boniface General Hospital Research Centre and,

Department of Physiology, Faculty of Medicine, University of Manitoba, Winnipeg, Canada Tel.: + $12042353412 ; ;$

Fax: +1 2042336723

tduhamel@sbrc.ca 